\title{
CHEMICAL CHARACTERIZATION AND SIZE DISTRIBUTION OF ATMOSPHERIC PARTICLES IN URBAN AREA - PRELIMINARY STUDY
}

\author{
Elba Calesso Teixeira \& Daniela Migliavacca \\ Fundação Estadual de Proteção Ambiental \\ Rua Carlos Chagas, 55/707 - Porto Alegre, RS \\ Josete Dani Sanchez \\ Fundação de Ciência e Tecnologia do Rio Grande do sul \\ Porto Alegre, RS \\ Jandyra Fachel \\ Departamento de Estatística \\ UFRGS - Porto Alegre, RS
}

\section{ABSTRACT}

The present work is a preliminary study with the aim of characterize the particle size and the chemical composition of aerosols in the Charqueadas County in Rio Grande do Sul State, Brazil, in order to better identify the sources responsible for alterations in the air quality. Seven filters were used for collecting material on thin nucleopore polycarbonate membrane $(0,4 \mu \mathrm{m})$ during March/1996 to July/1996. X-ray energy dispersive scanning electron microscopy was used to determine the chemical composition of aerosol particles, and 21 elements were then analysed. 
Particle size distribution was measured by SEM-EDX analysis, and also by automated image technique. Nonhierarchical cluster analysis was applied to identify the types of particles present in the samples. This procedure resulted in the definition of 8 groups of particles containing $\mathrm{Fe}, \mathrm{Zn}, \mathrm{Si}, \mathrm{Al}, \mathrm{S}, \mathrm{Ca}, \mathrm{Na}$ and $\mathrm{K}$, that revealed the chemical heterogeneity of aerosols in Charqueadas County. The particle size analysis showed the predominance (around $80 \%$ of all analyzed particles) of the fraction $\leq 10 \mu \mathrm{m}$ (dia) with the highest concentration of these particles located in the size $\leq 2.0 \mu \mathrm{m}$ (dia). Data from particle size distributions, including Falk and Ward parameters, were combined with meteorological parameters and subjected to Hierarchical Cluster Analysis and Discriminant Analysis. This procedure allowed particlebased features and meteorological variables to be integrated for potentially better discriminant capability.

\section{RESUMO}

O presente trabalho consiste em um estudo preliminar com o objetivo de caracterizar o tamanho de partícula e a composição elementar dos aerossóis no Município de Charqueadas no estado do Rio Grande do Sul, Brasil, a fim de identificar melhor as fontes que tem provocado alterações da qualidade do ar. Sete filtros foram coletados em membrana filtro de policarbonato $(0,4 \mu \mathrm{m})$ no período de Março/96 à Julho/96. Microscopia eletrônica com energia dispersiva de Raio-X foi usado para caracterizar a composição elementar de aerossóis coletados em amostrador de ar. Distribuição de tamanho de partícula foi realizada aplicando além do SEM-EDX, a técnica analisador de imagem automático. Análise de Cluster não hierárquica foi aplicada para identificar os tipos de partículas. Estes dados resultaram na definição de 8 grupos de partículas contendo $\mathrm{Fe}, \mathrm{Zn}$,

30 Rev. Ciência e Natura, Santa Maria, 21: $29-50,1999$. 
$\mathrm{Si}, \mathrm{Al}, \mathrm{S}, \mathrm{Ca}, \mathrm{Na}$ e $\mathrm{K}$, revelando heterogeneidade química dos aerossóis no Município de Charqueadas. A distribuição granulométrica mostroupredominância de tamanho $\leq 10 \mu \mathrm{m}$, cerca de $80 \%$ do total de partículas analisadas, sendo que o percentual mais elevado foi verificado na fração de $1 \mu \mathrm{m}$ e $2 \mu \mathrm{m}$. Os dados de distribuição granulométrica, juntamente com as variáveis meteorológicas foram avaliados, aplicando Análise de Agrupamento Hierárquico, pelo método de Ward's, e Análise Discriminante.

Este procedimento permitiu que as variáveis meteorológicas e as características das partículas fossem integradas para melhor capacidade discriminatória.

\section{INTRODUCTION}

Fine particles, < $10 \mu \mathrm{m}$ (dia), with heterogeneous chemical composition are emitted from several anthropogenic sources to the atmosphere. Fine particles contain large proportions of highly toxic chemical species and are more closely related to the anthropogenic sources. The composition and the particle size are parameters that rule several factors such as inhalation, toxicity, deposition, water vapor nucleation, light scattering etc. Relating to the chemical heterogeneity of aerosols (i.e. the chemical diversity of particles as a function of their sources) the analysis of individual particles can be carried out in order to identify the sources.

Several studies have been performed on the characterization of particles in the environment to help in the identification of anthropogenic sources (XHOFFER et al, 1991; ROMO-KROGER, 1990; KATRINAK et al, 1995; MALDEREN et al., 1996). The results of these studies report the variation of particle types, and their classification in several groups. 
In Southern Brazil, particulate matter has been a matter of concern, due to the low efficiency of emissions control systems for fine particles. The coal-processing and steel industry activities have been responsible for alterations in the air quality in some areas of Rio Grande do Sul State. Charqueadas County, located in the Baixo Jacuí Region, has shown problems with particulate contamination (TEIXEIRA, 1998; SANCHEZ et al., 1995). In this county there are anthropogenic sources (a steel industry and a coal-fired power station) whose emissions have produced alterations in air quality. This situation is likely to deteriorate with the increase in coal combustion for energy generation in this region following the installation of Jacui I Power Station. Considering the above, the aim of this work is to contribute to the determination of size distribution and chemical characterization of atmospheric particles in the Charqueadas County in order to improve the identification of the sources of atmospheric contamination.

\section{MATERIAL AND METHODS}

\section{Sample collection and preparation}

Samples of atmospheric particles were collected at the nearest site to the polluting sources within Charqueadas County (Figure 1). Sampling occurred from March to July 1996: 3/14/96 (filter 1), 3/23/96 (filter 2), 5/18/96 (filter 3), 6/22/96 (filter 4), 6/30/96 (filter 5), 7/6/96 (filter 6), 7/13/96 (filter 7). Samples used in the determination of total particles were collected in an air sampler on a $0,4 \mu \mathrm{m}$ dia. pore size nucleopore polycarbonate membrane filter. These systems were connected to a vacuum pump, which was operated at a flow rate of approximately $50 \mathrm{~L} / \mathrm{min}$ and equipped with an 
automatic timer system and a flow meter. The samples collected were stored in a desiccator until the analysis of elemental composition were done.

\section{Individual particle analysis}

Samples were analyzed using X-ray energy dispersive scanning electron microscopy, Joel-model JSM T330-A, equipped with a Be window. The samples were coated with a carbon layer when analysed in the microscope in order to improve the conductivity and to prevent thermal damage.

For each particle an X-Ray spectrum was acquired for $60 \mathrm{~s}$ at energies of $15 \mathrm{KeV}$, a beam current of $500 \mathrm{pA}$ and an accelerating voltage of $20 \mathrm{KeV}$, with relative dead times of $28 \%$. The Tracor-Northern program MICROQ was used to reduce each spectrum by its comparision to the regions of interest from standard spectra for each of the 21 studied elements: $\mathrm{Al}, \mathrm{Si}, \mathrm{Fe}, \mathrm{Ca}, \mathrm{Cl}, \mathrm{Cr}, \mathrm{Cu}, \mathrm{F}, \mathrm{K}, \mathrm{Mg}, \mathrm{Mn}, \mathrm{Na}, \mathrm{Ni}, \mathrm{P}, \mathrm{S}, \mathrm{Si}, \mathrm{Ti}, \mathrm{Mo}, \mathrm{V}, \mathrm{Sn}$ and $\mathrm{TI}$. Some elements were not analyzed due to the high detection limit (1000 ppm).

\section{Size Distribution}

Particle size distribution was evaluated by an OPTOMAX VAMS 6.05 automated image analyzer, and the SEM method. The image was obtained with the $\mathrm{BH}-2$ Olympus metallographic microscope and objective lens IC 50. Thin sections containing samples analyzed in this microscope were the same as those prepared for SEM observation. The thin section received the image treatment selected by longest dimension and the analysis 
area was split into quadrants, counting 5,000 particles, in a total of seven samples. Data obtained by this technique were separately analyzed, since it was not possible to identify the same particle by both techniques (optical analyzer and SEM).

\section{Statistical Analysis}

The chemical data was processed using computer software SPSS for Windows (Statistical Package for the Social Sciences). Nonhierarchical Cluster analysis was applied to identify different types of particles, or groups of particles in a same data set. A cluster represents particles with similar composition. Each cluster is represented by a centroid, which is the average composition of the members of the cluster. A nearest seed point is used to classify all particles according to their distance from the centroids of the clusters. The centroid is recalculated for the new cluster. This step is repeated until no more reassignments take place.

In the particle size distribution, the $75^{\text {th }}$ percentile was used as one of the variables to parameterize the size distribution. Also Folk and Ward's parameters were employed for additional characterization. These parameters were: mean $(\mathrm{M})$, which characterizes the location; median (MZ) which is less sensitive to outlier values; kurtosis (Kg) and skewness(Ski).

The data from the particle size distributions obtained in each filter was previously separated by Hierarchical Cluster Analysis, using Ward's method. From the resulting Univariate Analysis of Variance Test (ANOVA) and Discriminant Analysis to identify variables with significant discriminatory power were in this particular order applied. 


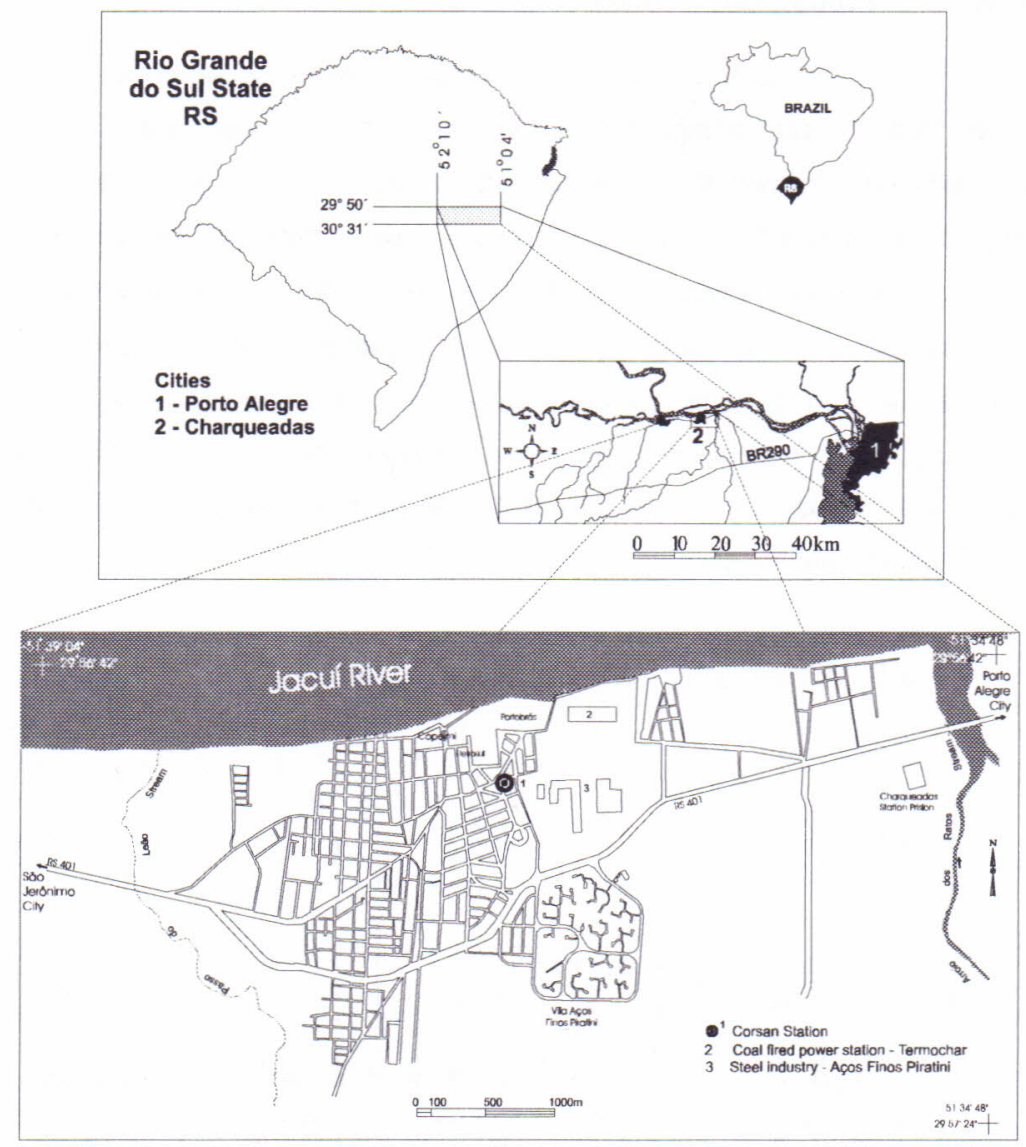

Figure 1. Location of air sampling station - Charqueadas County 


\section{RESULTS AND DISCUSSIONS}

\section{Elemental Composition Analysis}

Sizes and elemental composition were determined in 570 particles from 7 filters sampled on different dates. The presence of one or more elements showed the heterogeneity in the chemical composition of each particle. Figure 2 shows the box-plot, representing the median of the measured (\%) fraction of elemental chemical composition by the small square and the inter-quartile deviation by the larger rectangle. The outer error bars represent $\mathrm{Fe}$ and $\mathrm{Si}$ with percentage values of chemical composition, respectively, to $21 \%$ and $18 \%$, while the values for $\mathrm{Al}, \mathrm{S}, \mathrm{Ca}$ and $\mathrm{Na}$ varied between $4.9 \%$ and $7.4 \%$. The values for all other elements were close to zero and some outliers were found.

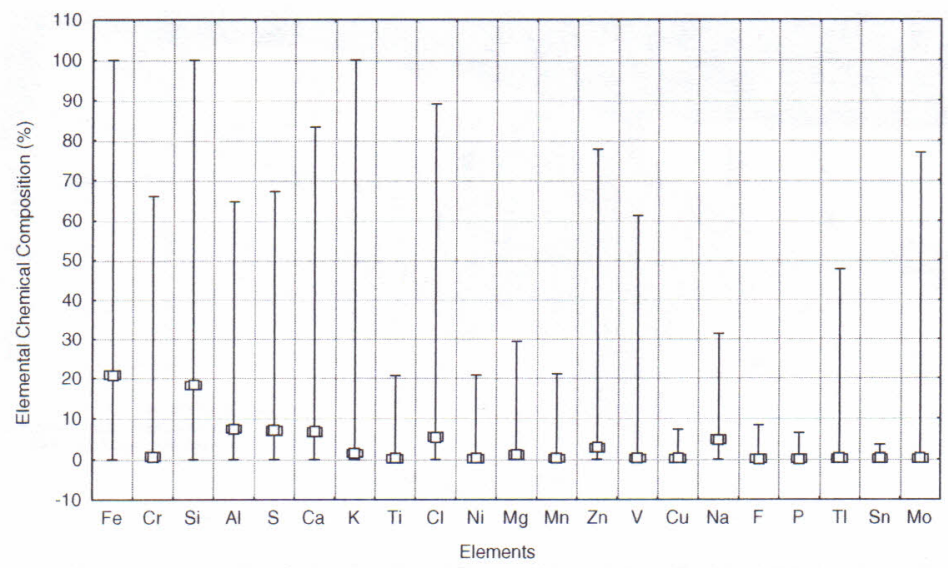

Figure 2. Box-plots representing percentile fractions of chemical composition analyzed by SEM-EDX

To verify the correlation between the elements, Pearson's correlation coefficient was applied. The correlation matrix, resulting from raw

36 Rev. Ciência e Natura, Santa Maria, 21: $29 \quad-50,1999$. 
data, is represented in table 1 and the significant coefficients were considered for a better interpretation. These data show a correlation between several pairs of elements such as $\mathrm{Fe}, \mathrm{Si}, \mathrm{Al}$, followed by $\mathrm{Mg}, \mathrm{Na}, \mathrm{Cl}, \mathrm{P}, \mathrm{S}, \mathrm{Ca}$, $\mathrm{Zn}$, and $\mathrm{Cu}$.

Cluster analysis, one of the main statistical treatments applied in this study, was used to identify the distinct types of particles. This analysis resulted in the definition of 8 clusters (Table 2), as defined by their central points (centroids), that can be defined in this case as the percentile average of measurements of elemental chemical composition of particles. The elements used in cluster analysis were $\mathrm{Al}, \mathrm{Ca}, \mathrm{Cr}, \mathrm{Cu}, \mathrm{Fe}, \mathrm{K}, \mathrm{Mg}, \mathrm{Mn}, \mathrm{Na}, \mathrm{Ni}$, $\mathrm{P}, \mathrm{S}, \mathrm{Si}, \mathrm{Ti}$ and $\mathrm{Zn}$. The other elements (Mo, V, Sn, Cl and TI) were excluded because they presented a percentile measurement $\leq 1$ for all particles analyzed. The nature, source, variation in the relative abundance and particle's size for each cluster formed will subsequently be discussed in detail.

Fe-rich particles (groups 1 and 6)

Considering Fe-containing particles, it was possible to distinguish two groups: group 1, with average composition value of 90.5 $\%$ and group 6, with $47 \%$. Group 6 particles were associated to other elements $(\mathrm{Zn}, \mathrm{S}$, and $\mathrm{Si})$ with average composition range from $10 \%$ to $7.8 \%$. Fe-rich particles from Group 1 were predominantly spherical, with rough surface and concentrated in the finer fraction $(33 \% \leq 2.0 \mu \mathrm{m}$ and $68 \% \leq 10.0 \mu \mathrm{m}$ ). Other authors (XHOFFER et al., 1991) also verified this typede 
Table 1. Correlation Matrix for the 21 elements determined.

\begin{tabular}{|c|c|c|c|c|c|c|c|c|c|c|c|c|c|c|c|c|c|c|c|c|c|c|}
\hline Element & $\mathrm{Fe}$ & $\mathrm{Cr}$ & $\mathrm{Si}$ & $\mathrm{Al}$ & S & $\mathrm{Ca}$ & $\mathrm{K}$ & $\mathrm{Ti}$ & $\mathrm{Cl}$ & $\mathrm{Ni}$ & $\mathrm{Mg}$ & $\mathrm{Mn}$ & $\mathrm{Zn}$ & V & $\mathrm{Cu}$ & $\mathrm{Na}$ & $\mathrm{F}$ & $\mathrm{P}$ & $\mathrm{TI}$ & $\mathrm{Sn}$ & $\mathrm{Mo}$ & d \\
\hline \multicolumn{23}{|l|}{$\mathrm{Fe}$} \\
\hline $\mathrm{Cr}$ & $\star \star$ & & & & & & & & & & & & & & & & & & & & & \\
\hline $\mathrm{Si}$ & $-\star \star \star$ & $-^{\star}$ & & & & & & & & & & & & & & & & & & & & \\
\hline $\mathrm{Al}$ & $-n^{* \star *}$ & ... & $\star \star \star \star *$ & & & & & & & & & & & & & & & & & & & \\
\hline $\mathrm{S}$ & $-\star \star \star \star x$ &.. & $-\star \star \star$ & $-{ }^{\star \star \star \star}$ & & & & & & & & & & & & & & & & & & \\
\hline $\mathrm{Ca}$ & $-^{* \star \star}$ & $\ldots$ & $-{ }^{\star \star *}$ & $-* \star \star$ & $\star \star \star \star *$ & & & & & & & & & & & & & & & & & \\
\hline $\mathrm{K}$ & $-\star \star \star \star$ & ... &.. &.. & ... & $-^{-}$ & & & & & & & & & & & & & & & & \\
\hline $\mathrm{Ti}$ & .. & ... & $\star \star$ & $\pi \star \star$ & ... & ... &.. & & & & & & & & & & & & & & & \\
\hline $\mathrm{Cl}$ & $-\star \star \star$ & .. & $-* \star$ & * & .. & ... & $\star \star \star \star$ & .. & & & & & & & & & & & & & & \\
\hline $\mathrm{Ni}$ & $\ldots$ & $\ldots$ & ... & ... & .. & .. & ... & 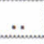 & ... & & & & & & & & & & & & & \\
\hline $\mathrm{Mg}$ & 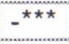 & .. & .. & $\star * \star *$ & $\star \star \star \star$ & $-{ }^{*}$ & $\ldots$ &. & $\star \star \star *$ & .. & & & & & & & & & & & & \\
\hline $\mathrm{Mn}$ & ... & .. & $l^{\star \star}$ & $\star \star \star \star$ & ... & $\ldots$ & .. & .. & .. & ... & $\star \star$ & & & & & & & & & & & \\
\hline $\mathrm{Zn}$ & $\ldots$ & $\ldots$ & $-{ }^{\star \star \star}$ & $\star \star \star \star$ & $\star \star \star \star$ & $-{ }^{\star \star}$ & $\ldots$ & .. & ... & ... & $\star \star \star \star$ & $\star \star \star \star$ & & & & & & & & & & \\
\hline V &.. & 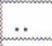 & ... & ... & .. &.. & $\ldots$ & .. & .. & $\star \star \star \star$ & .. & .. & ... & & & & & & & & & \\
\hline $\mathrm{Cu}$ & $-{ }^{\star \star \star}$ &.. & $-{ }^{\star \star}$ & ... & $-\star \star \star$ &.. & .. &.. & $\star \star$ & $\ldots$ & .. & ... & ... & in & & & & & & & & \\
\hline $\mathrm{Na}$ & $-{ }^{\star \star \star}$ &.. & $-{ }^{\star \star \star}$ & $\star \star *$ & .. & $\star *$ & ... & $\ldots$ & $* * *$ & $\ldots$ & $\star * *$ & .. & .. & . & 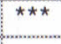 & & & & & & & \\
\hline$F$ & $\star \star \star$ & .. & $-^{\star}$ & .. & .. & ... & .. & .. & ... & ... & .. & ... & ... & . & ... & ... & & & & & & \\
\hline $\mathrm{P}$ & $-\star \star \star$ & .. & $-\star$ & ... & ... & .. & ... & .. & $\star \star \star *$ & ... & $\star \star \star \star$ & ... & $\star \star \star \star$ & . & * & $\star * \star *$ & . & & & & & \\
\hline TI &. & .. &. &. & .. & .. & . & .. & .. & $\cdots$ & .. & $\cdots$ & $\cdots$ & &. & $\cdots$ & . &.. & & & & \\
\hline $\mathrm{Sn}$ & 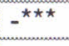 & .. & t** & $-^{*}$ & $-^{\star \star \star \star}$ & .. &.. &.. & ... & .. & $-^{*}$ &. & $E^{*}$ & t*** & ${ }^{* \star \star *}$ & **** & . &. & t*** & & & \\
\hline Mo & .. &.. & .. &. &.. & $\ldots$ & .. &. &.. & .. & .. &. & .. & $\ldots$ &.. & .. & $\therefore$ &.. &.. & .. & & \\
\hline d & .. & ... & ${ }^{\star \star \star}$ & .. & .. & $\ldots$ & $\star \star \star$ & ... & $\star \star \star \star$ & .. & ... & ... & .. & ... & $\ldots$ & $-\star \star \star$ & ... &.. & ... & $-\star \star \star$ & ... & \\
\hline
\end{tabular}


Table 2. Centroid of variables (percentage measurements of the element in the particle's composition) for the types of particles sampled in the Charqueadas County, determined by Cluster Analysis.

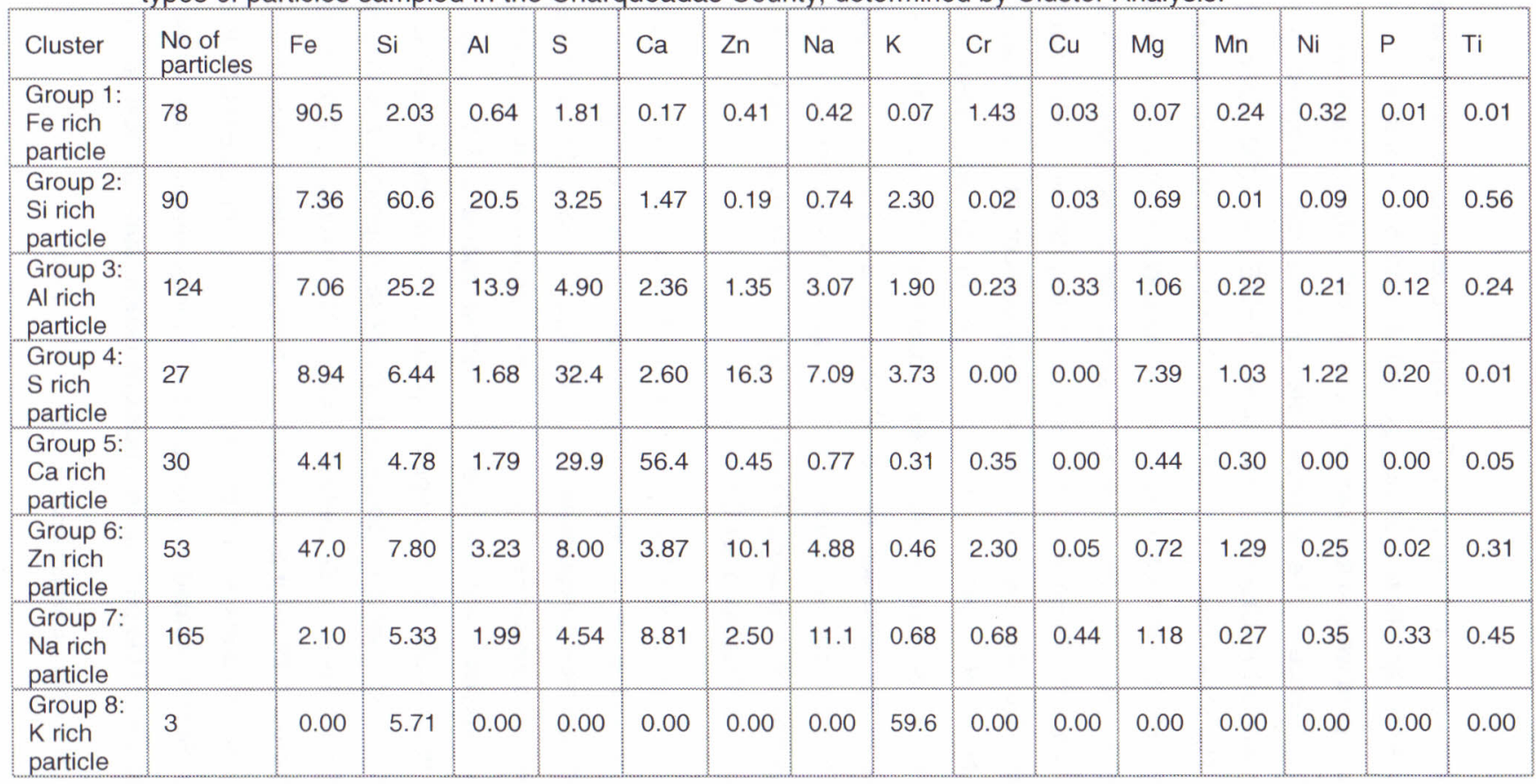


of morphology in Fe -rich aerosols. Zinc particles associated with $\mathrm{Fe}$ showed a predominantly spherical morphology and around $53 \%$ and $83 \%$ of all particles analyzed were in the fraction $\leq 2.0 \mu \mathrm{m}$ and $\leq 10 \mu \mathrm{m}$, respectively. The significant presence of $\mathrm{Fe}$ in particulate confirms data obtained in other studies conducted in Charqueadas County (TEIXEIRA, 1998; SANCHEZ et al., 1995). The steel industry located in this County is probably responsible for the Fe-rich particles, and such hypothesis is visually confirmed by the reddish color of their emissions (iron oxide). Besides, the association of $\mathrm{Zn}$ to $\mathrm{Fe}$ clearly shows the influence of the steel company on air contamination in Charqueadas County. These results are in agreement with data obtained by MALDEREN et al.(1994) who found $\mathrm{Zn}$ and Fe strongly associated in aerosols. These authors consider steel industry an important process that contributes to the emission of $\mathrm{Zn}$. Particulate are emitted in significant quantity since the company doesn't have, up to the moment, a system to control atmospheric emissions FEPAM, (1996) and alterations in air quality have occurred in Charqueadas County.

Cluster Analysis distinguished two groups of particles containing Si and Al. In group 2 we find Si-rich particles strongly associated with $\mathrm{Al}$, with average composition values of $60.6 \%$ and $20.5 \%$, respectively. Other elements, such as $\mathrm{Fe}, \mathrm{S}, \mathrm{K}$ and $\mathrm{Ca}$, were shown also to be associated with these particles, with average composition values $\leq 7.4 \%$. Group 3 particles, although also Si- (average composition 25.2\%) and Al-rich (average composition $13.9 \%$ ), weren't associated with those of group 2, because group 3 included particles with Si content $<40 \%$. The fraction $\leq 2.0 \mu \mathrm{m}$, which represents around $29 \%$ of all 90 particles identified, mostly showed rounded shape and smooth surface, and probably originated in the ELETROSUL coalfired Power Station located in Charqueadas County. Although the station has a system to control the particulate emissions (electrostatic precipitator), a

40 Rev. Ciência e Natura, Santa Maria, 21: $29 \quad-50 \quad, 1999$. 
fraction is emitted to the atmosphere, since the efficiency of this device diminishes as the particle size decreases (mainly $<10 \mu \mathrm{m}$ ). The morphology of particles identified in this work is in agreement with data reported in other studies (XHOFFER et al., 1991). According to these authors, the spherical particles consisted of alumino silicates are typical of fly ash from coal combustion. These particles, formed in high temperatures, generate a typical spherical shape, after the solidification of the fused material. However, the natural contribution of soil can be also responsible for these alumino silicaterich particles and only the morphology can sometimes differentiate their source. In the present study, particles with size ranging between 3 and 10 $\mu \mathrm{m}$, showed varied morphology, many of them are amorphous, and are characterized as soil-dust-derived. The association between the particle size and its source has been reported in several works(XHOFFER et al., 1991; MALDEREN et al., 1996). The authors report that fly ash particles emitted by coal power plants are generally smaller than those derived from soil.

S-rich particles (groups 4 and 5)

Particles containing $S$ were split into two clusters. The group 4 contains particles strongly associated with $\mathrm{Zn}$ and, in lesser intensity, to $\mathrm{Fe}$, $\mathrm{Mg}, \mathrm{Na}, \mathrm{Si}$ and $\mathrm{K}$, with average percentage $<11 \%$. Around $37 \%$ of S-rich particles are in the $\leq 2 \mu \mathrm{m}$ fraction and $67 \%$, in the $\leq 10 \mu \mathrm{m}$ fraction. These particles were predominantly finer $(\leq 2 \mu \mathrm{m})$ and spherical. $S$ and $\mathrm{Zn}$ containing particles are originated, specially, the steel industry located in Charqueadas County

In group $5, \mathrm{~S}$ is strongly associated with $\mathrm{Ca}$, with average percentage values of $56 \%$ and $30 \%$, respectively. In these particles small contents of $\mathrm{Fe}(4.4 \%)$ and $\mathrm{Si}(4.8 \%)$ were also found. The finer fractions, $\leq 2 \mu \mathrm{m}$ and $\leq$ 
$10 \mu \mathrm{m}$, that account for $33 \%$ and $73 \%$ of all particles analyzed, showed rounded, spherical and rectangular shapes.

The particles containing $\mathrm{Ca}$ and $\mathrm{S}$ are generally identified as $\mathrm{CaSO}_{4}$. The presence of $\mathrm{CaSO}_{4}$ particles in the atmosphere is not unusual and has been connected to several different sources (MALDEREN et al.1996). In this study, the most probable anthropogenic contribution of $\mathrm{CaSO}_{4}$ is the power station, despite the presence of a controlling system for particulate emissions. As previously mentioned, this kind of apparatus presents a reduced efficiency in the finer sizes $(\leq 10 \mu \mathrm{m}) . \mathrm{CaSO}_{4}$ as a result of coal combustion was proposed by other authors (XHOFFER et al., 1991; TEIXEIRA, 1998), who showed the presence of $\mathrm{CaSO}_{4}$ in fly ash particles. However, the occurrence of secondary reactions which lead to the formation of these particles is a hypothesis that must not be discarded. Sulfates can experience a number of reactions in the atmosphere, yielding a variety of complex compounds (POST and BUSECK,1984).

Na-rich particles (group 7)

This type of particle was classified as group 7. Within this group it is possible to distinguish associations with other elements such as $\mathrm{Ca}, \mathrm{Si}, \mathrm{S}$ and $\mathrm{Fe}$ with average percentage varying between $11.1 \%$ and $2.1 \%$. In the present study, the $\mathrm{Cl}$ content wasn't evaluated but it is well known that this element is often associated with $\mathrm{Na}$. These elements can be considered as originating from sea salts. Around $32 \%$ of all particles in this group present a size $<2.0 \mu \mathrm{m}$, and $90 \%$ of them $<10 \mu \mathrm{m}$.

K-rich particles (group 8)

The small number of observations of the particles analyzed didn't allowed a detailed description of this group.

42 Rev. Ciência e Natura, Santa Maria, 21: $29 \quad-50 \quad, 1999$. 


\section{Particle size distribution}

The particle size distribution was obtained by the image analysis technique. Figure 3 present values of particle size distribution for each fraction to all particles analyzed in the seven filter samplers. Particle size analysis shows a dominance of particles $<10 \mu \mathrm{m}$. Around $40 \%$ were included in the $\leq 2 \mu \mathrm{m}$ fraction, and $80 \%$ of all particles analyzed were within the $0-10 \mu \mathrm{m}$ size range.

In order to summarize all information on particle size distribution for the seven samples, filters 1 to 7 , they were represented by the $75^{\text {th }}$ percentile. To this variable, were added the Folk and Ward (FOLK and WARD, 1957) parameters (mean, median, kurtosis and skewness) and meteorological data (wind velocity and direction, rainfall and temperature). This procedure allowed particle-based feature and meteorological variables to be integrated for better discriminant capacity.

Cluster analysis and discriminant analyses were applied to data presented in table 3 . The hierarchical cluster analysis resulted in the formation of 3 groups: group 1- filters 1 and 2, group 2 - filters 3, 4, 5, 7 and group 3- filter 6. This analysis resulted in an alternative classification of samples, describing the similar behavior of particle size distribution and meteorological conditions.

The group 3 , characterized by filter 6 , showed the more significant percentage of particles in the fine fraction ranging from 0.3 to $0.5 \mu \mathrm{m}$, this was confirmed by the higher frequency of data shown by the skewness and kurtosis. Group 1 was also characterized by the same wind direction (SE). Group 2 (filters 3, 4, 5 and 7) was characterized basicaly by the direction of wind, SW 
Table 3. Meteorological data, particle size, represented by the $75^{\text {th }}$ percentile, Folk and Ward's statistic parameters.

\begin{tabular}{|c|c|c|c|c|c|c|c|}
\hline Filter & 1 & 2 & 3 & 4 & 5 & 6 & 7 \\
\hline Date & $3 / 14 / 96$ & $3 / 23 / 96$ & $5 / 18 / 96$ & $6 / 22 / 96$ & $6 / 30 / 96$ & $7 / 6 / 96$ & $\begin{array}{l}7 / 13 / 9 \\
6\end{array}$ \\
\hline $\begin{array}{l}\text { Wind velocity } \\
\left(\mathrm{m} / \mathrm{s}^{2}\right)\end{array}$ & 1.87 & 2.93 & 1.54 & 1.88 & 2.02 & 1.94 & 3.66 \\
\hline $\begin{array}{l}\text { Wind direction, } \\
\text { degree }\end{array}$ & $\begin{array}{l}129 \\
(S E)\end{array}$ & $\begin{array}{l}136 \\
\text { (SE) }\end{array}$ & $\begin{array}{l}195 \\
(S W)\end{array}$ & $\begin{array}{l}215 \\
(S W)\end{array}$ & $\begin{array}{l}218 \\
(S W)\end{array}$ & $\begin{array}{l}173 \\
(S)\end{array}$ & $\begin{array}{l}239 \\
(S W)\end{array}$ \\
\hline Rainfall ( mm ) & 1.50 & 2.60 & 0.00 & 23.9 & 9.70 & 6.90 & 0.00 \\
\hline $\begin{array}{l}\text { Mean } \\
\text { temperature }\left({ }^{\circ} \mathrm{C}\right)\end{array}$ & 25.3 & 24.3 & 18.7 & 12.0 & 9.43 & 10.2 & 14.5 \\
\hline $\begin{array}{l}75^{\text {th }} \text { Percentile } \\
(\mu \mathrm{m})\end{array}$ & 5.90 & 2.70 & 2.50 & 4.10 & 3.10 & 0.70 & 3.70 \\
\hline Mean $(\mu \mathrm{m})$ & 5.18 & 2.56 & 2.32 & 3.81 & 2.87 & 1.06 & 3.45 \\
\hline Median ( $\mu \mathrm{m}$ ) & 2.50 & 1.10 & 1.30 & 1.10 & 1.50 & 0.50 & 1.70 \\
\hline Kurtosis & 25.2 & 38.2 & 58.0 & 47.1 & 28.9 & 153 & 50.0 \\
\hline Skewness & 4.26 & 5.18 & 6.16 & 5.66 & 4.48 & 10.6 & 5.72 \\
\hline $\begin{array}{l}\text { Standard } \\
\text { deviation }\end{array}$ & 8.12 & 4.78 & 3.88 & 6.59 & 4.30 & 2.72 & 6.11 \\
\hline
\end{tabular}

The distinction between the groups formed by cluster analysis was better evidenced when the Discriminant Analysis was applied, and the variable with more discriminatory power were analyzed. Table 4 displays the univariate F-ratio's (simple ANOVA) for each of the independent variables. Review of the significance levels of the individual variables shown in Table 4 reveals that on a univariate basis, the variables kurtosis, skewness, 
temperature and wind direction display significant differences between the group means.

Table 4. Test of Univariate Analysis of Variance (ANOVA) for the 3 groups obtained by Cluster Analysis.

\begin{tabular}{|l|l|l|}
\hline \multicolumn{1}{|c|}{ Variables } & \multicolumn{1}{c|}{$F$} & \multicolumn{1}{c|}{ Significance $(\mathrm{p})$} \\
\hline Wind direction & 19.06 & $0.0090^{*}$ \\
\hline kurtosis & 40.41 & $0.0022^{*}$ \\
\hline Mean & 2.264 & 0.2200 \\
\hline Median & 1.913 & 0.2613 \\
\hline $75^{\text {th }}$ Percentile & 2.655 & 0.1846 \\
\hline Rainfall & 0.282 & 0.7681 \\
\hline Skewness & 25.95 & $0.0051^{*}$ \\
\hline Standard deviation & 1.704 & 0.2915 \\
\hline Mean temperature & 8.776 & $0.0344^{\star}$ \\
\hline Wind velocity & 0.088 & 0.9176 \\
\hline
\end{tabular}




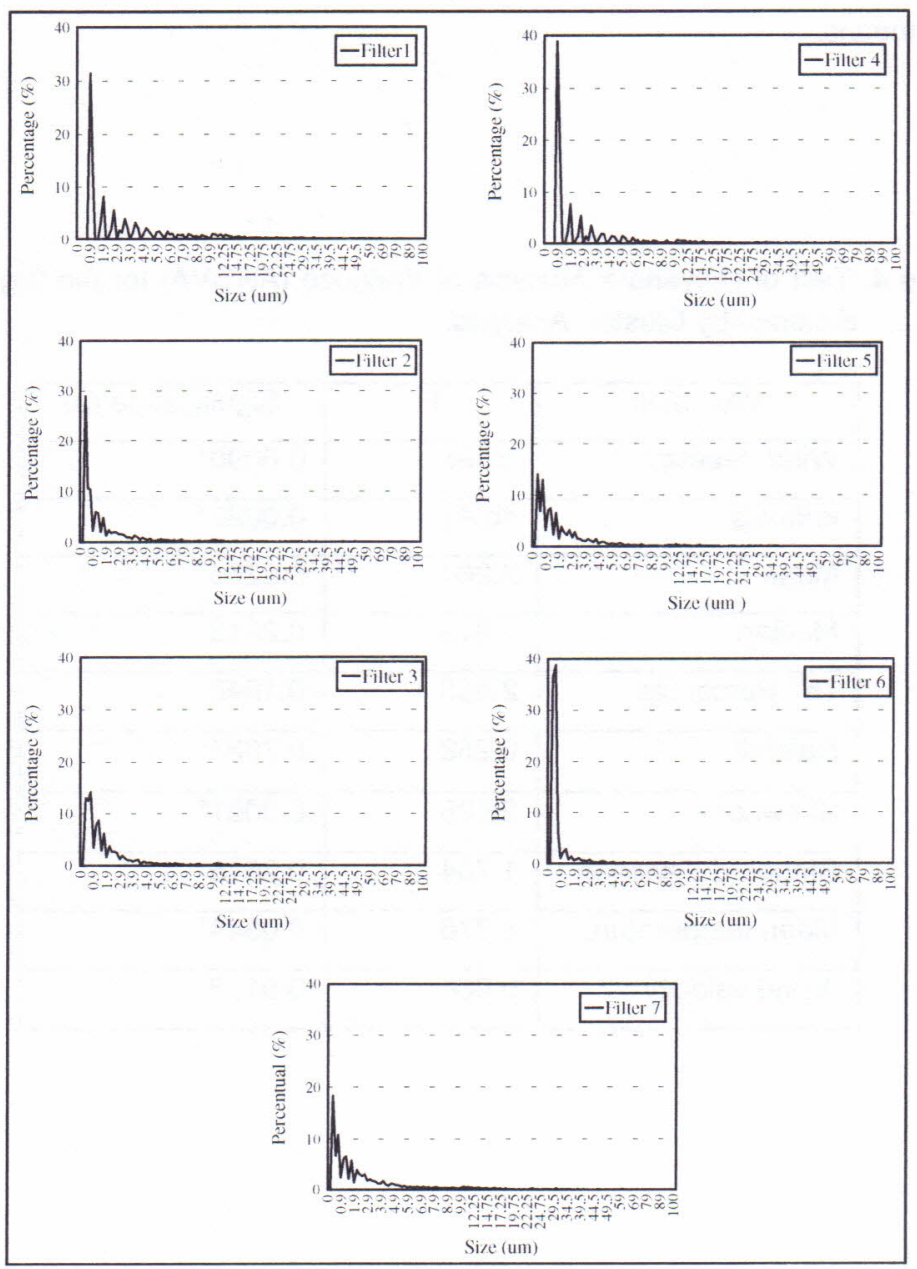

Figure 3:. Particle size distribution of seven samples identified as filters 1, $2,3,4,5,6$ and 7 .

46 Rev. Ciência e Natura, Santa Maria, 21: $29 \quad-50 \quad, 1999$. 
All the variables were considered for the Discriminant Analysis, resulting in two discriminating functions (table 5). From these data, the correlation between variables and the two discriminating functions, represented the loads that were observed. The highest coefficients or loading on function 1 are the variables kurtosis, skewness and temperature, the highest loadings on function 2 are the coefficient for the direction and velocity of the wind. The particle size were represented by the mean, median and $75^{\text {th }}$ percentile, and were variables with smaller discriminatory power. The velocity of the wind, although not significant on univariate ANOVA tests, is significant in the composition of the second discriminate function.

The classification results of the groups previously determined by discriminant analysis was $100 \%$ of cases correctly classified, which were used as an index to evaluate the quality of discriminant functions.

Table 5. Correlation of variables with the two canonical discriminating functions (Coefficient of Discriminating Functions).

\begin{tabular}{|l|l|l|}
\hline Variables & Function 1 & Function 2 \\
\hline Kurtosis & $0.91956^{\star}$ & -0.28780 \\
\hline Skewness & $0.90203^{\star}$ & -0.24756 \\
\hline Temperature & $0.75097^{\star}$ & -0.57675 \\
\hline Rainfall & -0.44179 & -0.02651 \\
\hline $75^{\text {th }}$ Percentile & -0.23664 & -0.04589 \\
\hline Mean & -0.22213 & -0.00882 \\
\hline Median & -0.20347 & -0.02727 \\
\hline Direction of winds & 0.13846 & $0.95802^{\star}$ \\
\hline Velocity of winds & 0.48017 & $0.87189^{\star}$ \\
\hline Standard deviation & -0.02100 & 0.08542 \\
\hline
\end{tabular}




\section{CONCLUSIONS}

The results obtained from the study of chemical and physical characterizations revealed the heterogeneity of aerosols and the predominance of fine particles $(<10 \mu \mathrm{m})$ in Charqueadas County. Nonhierarchical Cluster Analysis applied to data of chemical composition of particulate by the K-means method resulted in the formation of 8 groups of particles rich in $\mathrm{Fe}, \mathrm{Si}, \mathrm{S}, \mathrm{Ca}, \mathrm{Zn}, \mathrm{Cl}$ and $\mathrm{K}$, to the local in the Charqueadas County. The groups with the highest frequency consisted of $\mathrm{Fe}, \mathrm{S}, \mathrm{Zn}$ and $\mathrm{Si}$ $\mathrm{Al}$-rich particles for the majority of the samples studied, consistent with these elements originating in the existent local sources, the steel industry and the coal-fired power station.

The particle size distribution showed the predominance of the fraction $<10 \mu \mathrm{m}$ (inhalable particulate) for $80 \%$ of the particles analyzed. In this distribution, the largest amount of particles was in the fraction $<2 \mu \mathrm{m}$. Data from the particle size distribution was analysed through hierarchical Cluster and Discriminant Analysis. The results reveal that the variables kurtosis, skewness, temperature and direction of winds display significant difference between the group means.

In despite of the few data available, we can observe a contamination of the atmospheric particles enriched by metallic elements, which characterize well the anthropogenic sources (coal fired power station and siderurgic) in Charqueadas County

These particles are found mainly in the aerodynamic size and represent a potential risk to human health, since they can be inhaled and deposit within the pulmonary alveoli. Unfortunately, this situation could be worsened, due to the planned installation of another coal-fired power station close to the existent sources mentioned in this work.

48 Rev. Ciência e Natura, Santa Maria, 21: 29 - 50 , 1999. 


\section{ACKNOWLEDGEMENTS}

We acknowledge to FINEP/PADCT-GTM by the financial support for this work. Department Geofisica/USP and Fras-le by utilization SEM-EDX and automated image analyzer, respectively, for analysis.

\section{REFERENCES}

XHOFFER, C.; BERNARD,V.P.; VAN GRIEKEN, R. AND VAN DER AUWERA, L. Chemical characterization and source apportionment of individual aerosol particles over the North Sea and the English Channel using multivariate technique. Environ.Sci.Technol.1991, 25, 1470-1478.

ROMO-KROGER, C.M. Elemental analysis of airbone particulates in Chile. Environmental Pollution.1990, 68, 161-170.

KATRINAK, K.A.; ANDERSON, J.R. AND BUSECK, P.R. Individual particle types in the aerosol of Phoenix, Arizona. Environ. Sci. Technol.1995, 29, 321-329.

MALDEREN, V.H.; GRIEKEN, R.V.; BUFETOV, N.V. AND KOUTZNOGI,I. Chemical characterization of individual aerosol particles in Central Siberia. Envir. Sci. Techn. 1996, 30, 312-321.

TEIXEIRA, E.C. Avaliação da poluição hídrica e atmosférica em áreas de mineração e utilização de carvão do Baixo Jacuí, RS. FINEP-

PADCT/GTM. Technical Report, conv. $n^{\circ}$. 65.93.0322.00, 1998, 5 volumes.

SANCHEZ, J.C.D., TEIXEIRA, E.C.; ISAIA, T.; VECCHIO, G.; PESTANA, M.H.D. \& FORMOSO, M.L.L. Estudo de particulas totais em suspensão e metais associados na região do Baixo Jacui,R.S. In Proceedings of the $V$ Congresso Brasileiro de Geoquímica e III Congresso de Geoquímica dos Países de Lingua Portuguesa, Niterói, 1995, 5p. 
FEPAM. Fundação Estadual de Proteção Ambiental. Projeto de controle das emissões atmosféricas da Aços Finos Piratini, 1996.

POST, J.E. AND BUSECK, P. Characterization of individual particles in the Phoenix Urban aerosol using electron-beam instruments. Environ. Sci.Technol. 1984, 18, 35-42.

FOLK, R.L. AND WARD, W.C. Brazos river bar : a study in the significance of grain size parameters. Journal of Sedimentary Petrology. 1957, 27, 3-26. 